\section{Big bath and goodwill impairment}

\author{
Cristina Gonçalves ${ }^{1}$ \\ ${ }^{1}$ Universidade do Algarve, Escola Superior de Gestão, \\ Hotelaria e Turismo, Faro, Portugal

\section{Leonor Ferreira ${ }^{2}$} \\ ${ }^{2}$ Universidade Nova de Lisboa, Nova School of Business \\ and Economics, Lisboa, Portugal \\ Efigénio Rebelo ${ }^{3}$ \\ ${ }^{3}$ Universidade do Algarve, Faculdade de Economia, Faro, Portugal
}

\author{
Joaquim Santana Fernandes ${ }^{4}$ \\ ${ }^{4}$ Universidade do Algarve, Escola Superior de Gestão, \\ Hotelaria e Turismo, Faro, Portugal
}

\begin{abstract}
Purpose - To analyze the extent to which recognition of impairments in goodwill is associated with periods of negative results before these losses (big bath practices). To determine whether indebtedness and the capital market restrict the recognition of such losses in big bath practices.
\end{abstract}

Design/methodology/approach - Quantitative empirical study based on accounting and market data of companies listed on the Lisbon and Madrid stock exchanges (2007-2015), supported by multivariate regression models estimated using the generalized moments method (system GMM).

Findings - Impairment in goodwill is relevant in big bath practices, and there is great discretion in the use of this accrual. It can be concluded that companies adjust to capital market cycles. The positive relationship between the level of indebtedness and the impairment in goodwill suggests that any penalties from creditors do not condition the recognition of the impairments.

Originality/value - There is evidence of big bath practices being associated with companies with negative results and of the role of debt and capital markets as explanatory factors of big bath strategies that use impairments in goodwill.

Keywords - Goodwill impairment, Big bath, Indebtedness, Capital market
Received on

04/16/2018

Approved on

08/23/2018

\section{Responsible editor:}

Prof. Dr. Javier Montoya del

Corte

\section{Evaluation process:}

Double Blind Review

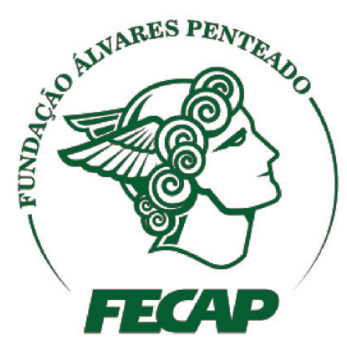

Review of Business Management 


\section{Introduction}

The recognition of impairment losses in goodwill (designated by Imp_GW) appears in the literature because of the loss of capacity to generate cash in the future (Brütting, 2011; Olante, 2013).

The verification and quantification tests of Imp_GW, according to International Accounting Standard (IAS) 36, have economic impacts (Harris \& Caplan, 2002), with reflections on the value of the company and the likelihood of recognizing the loss, its amount, and its timing. Ramanna and Watts (2012) identify three aspects that introduce high discretion into the recognition of Imp_GW: (i) GW's effect on cash-generating units, (ii) estimation of the deducted value of future cash flows, and (iii) determination of fair value of assets and liabilities.

There is evidence of opportunistic earnings management through Imp_GW. In particular, big bath practices and income smoothing depend on a set of factors, in addition to the accounting choice permitted by the standards. Several authors have analyzed this issue in different contexts and using various methodologies, but they have not reached a consensual conclusion. For instance, Carvalho (2015), Jahmani, Dowling, and Torres (2010), and Li, Shroff, Venkataraman, and Zhang (2011) found Imp_GW is used as a tool for earnings manipulation, while Avallone and Quagli (2015), Castro (2012), and Jordan and Clark (2004, 2015) do not confirm the hypothesis.

One other stream of research analyzes the factors inhibiting or facilitating earnings management policies, such as the capacity for credit negotiation (Beatty, Ramesh \& Weber, 2002; Beatty \& Weber, 2006; Riedl, 2004), the market value of the company (Chen, Kohlbeck \& Warfield, 2008; Giner \& Pardo, 2015; Jarva, 2009; Lee, 2011; Li et al., 2011; Li \& Sloan, 2017), and its indebtedness (Godfrey \& Koh, 2009; Hamberg, Paananen \& Novak, 2011). The conclusions are neither consensual, nor robust.

The lack of consensus in the various studies, together with criticisms from preparers, auditors, regulators, and investors, have motivated the ongoing process of reviewing IFRS 3 and support the relevance of this research, which has the following objectives: (i) to analyze to what extent the recognition of Imp_GW is associated with periods where earnings before Imp_GW are negative (big bath practices); (ii) to assess to what extent debt and capital markets restrict the recognition of Imp_GW in big bath practices.

This paper focuses on comparing Portuguese and Spanish companies, based on a sample of 105 companies with securities listed on the stock exchange (2007-2015), and it adopts a quantitative methodology and dynamic multivariate regression models, using panel data.

Although the companies apply international accounting standards / international financial reporting standards (IAS / IFRS) and are influenced by code law in both countries (Knobble \& Parker, 2004), there is evidence (e.g., Fernandes, Gonçalves, Warrior \& Pereira, 2016) of more conservative accounting behavior regarding the recognition of Imp_GW, in some companies, thus justifying some interest in this comparative analysis.

This study contributes to the literature in two ways: (i) by comparatively analyzing big bath practices in two countries, which apply the same accounting standards (IAS/IFRS) and are influenced by code law; (ii) by analyzing constraints to big bath practices that use Imp_ GW, such as debt and capital markets.

Our findings suggest the existence of earnings management policies based on the recognition of Imp_GW. So one may question whether the annual assessment of these losses is the best criterion for evaluating GW as guarantor of credible financial information. Thus, the study encourages those bodies responsible for accounting standardization to analyze the efficiency of the mechanisms involved in the recognition of Imp_GW, by pondering regulatory solutions to minimize the degree of discretion associated with the timing and value of these losses and thereby improving the credibility of financial information. 


\section{Literature Review}

\section{I Big bath practices}

Earnings management is associated with strategies to achieve benchmarks, namely the smallest variability in inter-period earnings (income smoothing), as a tool for managing shareholders' and other stakeholders' expectations, and the expectation of increasing future earnings (big bath accounting), following the penalization of present earnings. This paper analyzes negative earnings as an inducing factor of those practices.

Several authors (Henning, Shaw \& Stock, 2004; Li \& Sloan, 2017; Ramanna \& Watts, 2012; Riedl, 2004) analyze the recognition of Imp_GW in the context of managers' discretion, namely the amount and time of such recognition, notably through big bath practices, associated with the use of non-current items to manage earnings in periods where they are significantly low. This strategy is justified by the expectation that markets do not penalize companies in proportion to their losses, because investors focus more on the future and companies signal to the market improvements obtained after a bad result (Jordan \& Clark, 2004).

Walsh, Craig, and Clarke (1991) define big bath as the use of non-frequent items to adjust earnings and in situations of abnormal losses or gains, while Elliott and Shaw (1988) consider that big bath occurs when the impairment reported in special items represents more than 1 per cent of the accounting value of the assets. These practices are more likely in large companies than in small ones, although a big bath strategy has more impact on the latter (Sevin \& Schroeder, 2005).

Li et al. (2011) found evidence of big bath practices that use Imp_GW being associated with the presence of negative earnings, while AbuGhazaleh, al-Hares, and Roberts (2011), Beatty and Weber (2006), and Jordan and Clark (2015) associate big bath practices with recent changes of Chief Executive Officer
(CEO). However, the hypothesis that earnings manipulation (big bath) is associated with a new CEO was not validated by Avallone and Quagli (2015), Jordan and Clark (2004, 2015), and Ramanna and Watts (2012). These authors concluded that impairment recognition is associated with other factors, namely the market's perception or the effective deterioration of the assets. For example, Jordan and Clark (2004) conclude that companies recognized more Imp_ GW in 2002 probably because earnings were already diminished and the market would punish them relatively little if they were reduced. Van de Poel, Maijoor, and Vanstraelen (2009) conclude that impairment is recognized in periods where other losses are also recognized or in periods where earnings before impairment are relatively low, while Jahmani et al. (2010) suggest that managers manage the moment of Imp_GW recognition. In turn, Escribano (2015) and Francis, Hanna, and Vincent (1996) conclude that a history of Imp_GW recognition induces similar future behaviors.

In studies applied to Portuguese companies, Carvalho (2015) found evidence of big bath practices, while Castro (2012) did not find such practices. Alves (2013) confirmed the relevance of Imp_GW as a discretionary element of accruals. Escribano (2015) also concludes that these practices exist in Spanish companies.

Whereas the literature is not in agreement regarding the practice of using Imp_GW as an instrument for earnings manipulation, the following research hypothesis is considered:

H1: The recognition of Imp_GW is associated with negative earnings before the Imp_GW, ceteris paribus.

\subsection{Constraints to big bath practices}

\subsection{Debt}

Several studies associate the tendency not to recognize impairment, in the context of earnings management, with this being able to 
influence the debt capacity of companies, namely in the risk premium or in obtaining new loans (Beatty et al., 2002; Beatty \& Weber, 2006; Riedl, 2004).

When GW and other intangibles have a significant weight in total assets, creditors do not ignore the information contained in those items (Beatty, Weber \& Yu, 2008). The perception of credit risk may be flagged by debt-to-equity or liabilities-to-assets ratios. High levels of indebtedness encourage non-recognition of impairment in order not to increase those indicators and to avoid consequences in terms of debt negotiation. This behavior is not, however, generalizable. Beatty et al. (2002), for example, conclude that companies are willing to accept higher interest rates in order to maintain flexibility in their accounting options, thus weighing up other interests besides the cost of indebtedness alone, in particular those related to agency costs, litigation, or taxes (Beatty et al., 2008).

Other authors, notably AbuGhazaleh et al. (2011), Avallone and Quagli (2015), Beatty and Weber (2006), Godfrey and Koh (2009), Hamberg et al. (2011), Ramanna and Watts (2012), Vogt, Pletsch, Morás's, and Klann (2016), and Zhang (2008), associate indebtedness with options in accounting policy. Beatty and Weber (2006) suggest companies are less susceptible to recognizing Imp_GW when they have less negotiating capacity and accounting changes affect credit agreements. Zhang (2008), in turn, analyzes the relationship between conservative accounting policies and credit agreements, noting that there are minor inequalities in more leveraged companies and that lenders offer lower interest rates to more conservative borrowers. However, the author considers that more conservative borrowers are the ones most likely to violate contracts as a result of negative impacts. Ramanna and Watts (2012) also confirm that Imp_GW decreases when changes to debt contracts are at risk.

The results on discretion in the recognition of Imp_GW and indebtedness are neither consensual nor robust. Godfrey and Koh (2009) concluded that managers use discretionary power to reduce hiring costs and found a meaningful but non-robust relationship there. Hamberg et al. (2011) also tested the relevance of the debt ratio in recognizing these losses and concluded it was not significant, which is explained by the fact that Swedish legislation restricts the compulsory payment of dividends and such restrictions reduce the unpredictability of debt repayment.

Lapointe-Antunes, Cormier, and Magnan (2008) found negative relationships between both financial leverage and the need for funding and Imp_GW. These authors concluded that, in general, companies that increase debt or equity are not influenced by the fact that GW seems to be impaired.

Abughazaleh et al. (2011) did not find a significant relationship between the debt ratio and the recognition of Imp_GW. This absence is explained by less information asymmetry between managers and financiers, which would create few incentives to manage results. More recent studies have found no relationship between indebtedness and earnings management practices that use Imp_GW (Avallone \& Quagli, 2015; Oak, 2015; Vogt et al., 2016).

\subsubsection{Market value}

As a rule, market value proxies are treated as dependent variables. However, Alciatore, Easton and Spear (2000), Elliot and Shaw (1988), Francis et al. (1996), Riedl (2004), and Vogt et al. (2016) consider market value as a potentially explanatory variable. Some authors argue that Imp_GW recognition obliges managers to disclose information about fair value and expected future cash flows, which leads to updated investor expectations for future returns (Chen et al., 2008; Jarva, 2009; Lee, 2011; Li et al., 2011).

The recognition criteria for goodwill impairment require unverifiable estimates of future cash flow or market values, which are susceptible to manipulation (Holthausen \& Watts, 2001). However, if investors validate an 
evaluation measure and reward managers based on that measure, the latter will tend to manipulate it for their own benefit (Watts, 2003). Henning et al. (2004) confirm this manipulation (delay in the recognition of Imp_GW and strategic revaluation) to obtain shareholder approval, linked to certain objectives. Francis et al. (1996) include the performance of the market price and the variation in the book-to-market indicator as proxies of the decision to impair, that is, impairment recognition (expecting a negative relationship). They conclude that companies with poor performance in the market recognize higher impairment losses.

Alciatore et al. (2000) analyze the relationship between the stock price and asset impairment. They find a greater correlation between impairment values and returns in the previous quarter than between impairment and returns in the same period. Thus, they conclude that impairment tends to be reported after a fall in the stock price, suggesting that the market already incorporates at least part of that information. Chen et al. (2008) obtain similar results. Riedl (2004) uses three market proxies (return by industry, return by company, and return variation) and finds a significant negative relationship with Imp_GW.

$\mathrm{Li}$ and Sloan (2017) test the hypothesis that stock price correctly reflects all information about an inflated GW and its future devaluations. They test the value of shares in a previous period and in a current period, concluding that the decision to recognize Imp_GW is not a reflection of changes in estimated future cash flow, but rather a late response to a substantial extinction of GW benefits, already reflected by the market. In a study on Spanish listed companies, Giner and Pardo (2015) also use return ( $\mathrm{t}-1$ ) and market-tobook as market proxies and find only a meaningful relationship with the latter. Carvalho (2015) find a significant negative relationship between market-to-book and the recognition of Imp_GW in Portuguese companies.
Considering the diversity of conclusions and that in a big bath policy the option of reducing earnings can be conditional on the degree of financial leverage and the anticipation of a reduction in market return, consequently penalizing shareholders, the following hypothesis is established:

H2: The big bath practices of companies with negative earnings before Imp _ $G W$ are conditioned by indebtedness and the stock market, ceteris paribus.

\section{Empirical study}

This investigation follows a positivist approach (Watts \& Zimmerman, 1990) and seeks causal relationships among potentially explanatory variables of Imp_GW recognition. In the context of this theory, accounting practices are guided by the interests of agents, who seek to maximize their well-being. Watts and Zimmermann (1990) point to regulation to regulation, the costs of producing information, compensation plans, the degree of indebtedness, and the political costs associated with the size of the companies, as factors that influence these practices.

\section{I Universe and sample}

The research universe consists of companies with securities listed on the Lisbon and Madrid stock markets in the 2007-2015 period. This choice is based on the greater demand for transparency imposed by the supervisory authorities.

The historical influence of code law in both countries, compared to those of the common law tradition, is seen as a factor involving less protection of creditors and shareholders (La Porta, Lopez-de-Silanes, Shleifer \& Vishny, 1997). At the same time, the corruption perception index in 2015 (Transparency International, 2015) places Portugal and Spain in $28^{\text {th }}$ and $37^{\text {th }}$ position, respectively, in the world ranking $\left(16^{\text {th }}\right.$ and $22^{\text {nd }}$, respectively, in the ranking of European 
countries), which also suggests an environment with reduced legal protection.

Both countries have undergone several years of economic recession (2009-2013), with high unemployment, especially in Spain (in the order of 20\%). Spain has a gross domestic product (2016) that places it in fifth position in the European Union (Eurostat, 2018) and $13^{\text {th }}$ in the world ranking (Portugal in $46^{\text {th }}$ ), according to the World Bank (2018). As a result of the economic recession, combined with continued growth of public debt, Portugal was subjected to an economic and financial assistance program (2011-2014), which led to measures to promote greater budgetary rigor, stability of the markets, and financial and social spending cuts. While with a different degree of intervention, Spain also resorted to financial support to recapitalize its financial sector.

In terms of capitalization (World Federation of Exchanges, 2016), the difference between the two countries is the following: Spain is in $16^{\text {th }}$ place in the world ranking and Portugal is in $48^{\text {th }}$.

A sample of 105 companies (35 Portuguese and 70 Spanish) is drawn from a universe of 53 and 124 (in 2015), respectively. The financial sector and the sports sector are excluded, in order to enable the total comparability of the information. Companies with an International Securities Identification Number prefix different from PT or ES were also excluded. The data were directly and manually extracted from the consolidated reports and accounts of the companies, available on the online pages of the supervisory entities of the securities markets of Portugal and Spain.

The market data (stock prices) were obtained from www.bolsadelisboa.com.pt/ and www.bolsademadrid.es/.

In the Imp_GW analysis, 11 companies were excluded due to not presenting GW in their balance sheets (one is Portuguese and 10 are Spanish). An unbalanced final panel was obtained, containing 826 observations.

\subsection{Variables}

Several studies have chosen Imp_GW as a dependent variable, using either the positive amount of goodwill impairments (primary or deflated by the value of assets or by sales) or a binary form, defined as recognition or nonrecognition of Imp_GW. The logarithmically transformed carrying amount was chosen in order to reduce the asymmetry within the sample. Logarithmic transformation of the variables is a common procedure in continuous variables, with the interval $[0 ;+\infty[$, when used in economic/ financial studies. In this study, given the presence of the zero value (0), the transformation was performed with the expression ln (Imp_GW + 1).

The association between the recognition of Imp_GW in year $t$ (Ln_imp_GWt) and in the previous year $(t-1)$ is explored. Based on Beatty and Weber (2006), Elliot and Hanna (1996), Escribano (2015), and Francis et al. (1996), a positive association is expected between these two variables. The introduction of the dependent variable as independent violates the assumptions of exogenous regressors, and justifies the use of the Generalized Method of Moments (GMM) rather than ordinary least squares estimation or fixed and random effects estimation using panel data.

Negative net earnings ( $\mathrm{RL}_{-}$neg), before impairment, market return, and level of indebtedness are the variables of interest in this research. These variables are estimated for the whole sample, and are controlled by country and by industry (Industry Classification Benchmark, Level 1). The RL_neg variable intends to capture big bath practices that use Imp_GW recognition, in periods where earnings before such recognition are negative. The hypothesis is that in periods of bad economic crashes, the worsening of performance through Imp_GW is perceived by managers as having a minimal impact on stakeholders.

Market proxies, such as price to book value (PBV), stock returns (Ret), and return on equity (ROE), reflect investors' expectations or indicate the ability to generate future cash flow. 
PBV represents the relationship between market value per share and accounting value per share. It can be interpreted as a measure of the return of shares (Zhang, 2008) or as a proxy for future cash flow, so it is expected to be negatively associated with Imp_GW (e.g., Bamber \& Cheon, 1998). Other authors (e.g., AbuGhazaleh et al., 2011) advocate a positive association between these variables. Ret is an external measure, which indicates the market return to shareholders and also the economic performance of a company (Francis et al., 1996; Godfrey \& Koh, 2009) as well as its ability to generate future cash flows. Because Imp_GW signals the loss of capacity to generate future cash flows, this independent variable is expected to be negatively associated with Ret. Conversely, there is the following argument: managers tend to manage earnings in companies with low returns in order to disguise poor performance, so the association between market value per share and accounting value per share is positive. The Ret variable is included, for time $t$ (share price on $31^{\text {st }}$ December), as a potentially (explanatory) independent variable of Imp_GW to the extent that the closing of accounts is expected to be already affected by this market information, after accruals recognition. ROE is an accounting indicator of the company's performance, so better performance means the need for Imp_GW recognition (AbuGhazaleh et al., 2011; Chalmers, Godfrey \& Webster, 2011; Escribano, 2015; Giner \& Pardo, 2015), therefore, a negative relationship between ROE and Imp_GW is expected.

Total assets/total liabilities (DEBT) for period $t$ captures the relevance of financial leverage in decisions on Imp_GW. Because the theory suggests companies tend to increase earnings when financing-related negotiations are forthcoming, a negative relationship between DEBT and Imp_GW is expected (e.g. Ramanna \& Watts, 2012).

In addition to the variables of interest, a set of control variables is considered. The GW variable identifies the relative weight of GW in total assets (GW_assets). GW's deflation by total assets is justified to reduce the effect of the dimension asymmetry between the sample companies. A positive relationship between GW's relative weight variable in total assets and the respective impairment is expected. Companies with higher GW values tend to report higher impairment values (Abughazaleh et al., 2011; Zhang, 2008). CEO remuneration (RV_CEO) intends to determine to what extent bonuses associated with economic performance (earnings) influence decisions on the recognition of Imp_GW. Managers have incentives to delay the recognition of losses, including those related to GW (Beatty \& Weber, 2006; Ramanna and Watts, 2012), when this significantly effects their remuneration. A negative correlation between these variables is expected. Total assets (Ln_assets), BIG4, and Return on sales (ROS) are proxies for size, quality of auditing, and economic performance, respectively.

The public visibility of companies can soon encourage decreased earnings to reduce political costs (Watts and Zimmerman, 1978). Thus, a positive relationship between size and the dependent variable is expected.

The BIG4 variable is used (Escribano, 2015; Giner \& Pardo, 2015) to refer to the quality of supervision, as a disincentive for earnings management by the administration, and with the capacity to predict customer bankruptcy more timely and with greater likelihood, and therefore the risk of litigation. This auditors variable is also associated with a more conservative accounting perspective (e.g., Xu, Carson, Fargher \& Jiang, 2013), so a positive relationship with the dependent variable is expected.

ROS reflects the relationship between sales and earnings, so a negative relationship between this variable and Imp_GW is expected, as companies tend to maximize return on sales (Abuaddous, Hanefah \& Laili, 2014).

Table 1 lists the variables in the models to test, as well as their expected signs, and it lists the reference sources that support them theoretically and justify the selected proxies. 
Table 1 .

Independent variables

\begin{tabular}{|c|c|c|c|}
\hline Variable & Description & Expected sign & Reference \\
\hline BIG4 ${ }_{t}$ & Dummy: 1 if the auditor is a Big 4,0 otherwise & + & $\begin{array}{l}\text { Escribano (2015). } \\
\text { Giner \& Pardo (2015). }\end{array}$ \\
\hline Debt $_{t}$ & Debt $=\frac{\text { Total liabilities }_{\mathrm{t}}}{{\text { Total } \text { assets }_{\mathrm{t}}}}$ & - & $\begin{array}{l}\text { Avallone \& Quagli (2015). } \\
\text { Giner \& Pardo (2015). } \\
\text { Stenheim \& Madsen (2016). }\end{array}$ \\
\hline $\mathrm{GW}_{\text {anssets }}$ & $G W_{-}$assets $=\frac{G W_{t}}{{\text { Total } \text { assets }_{t}}^{\text {a }}}$ & + & $\begin{array}{l}\text { Abughazaleh et al. (2011). } \\
\text { Castro (2012). } \\
\text { Giner \& Pardo (2015). } \\
\text { Rammana \& Watt (2012). } \\
\text { Zhang (2008). }\end{array}$ \\
\hline Ln_assets $_{t}$ & Natural logarithm of net assets, deducted from GW in year $t$ & + & $\begin{array}{l}\text { Avallone \& Quagli (2015). } \\
\text { Hamberg et al. (2011). }\end{array}$ \\
\hline$\triangle \mathrm{PBV}_{\mathrm{t}}$ & $\begin{array}{c}P B V=\frac{\text { Price }^{\text {Dec }} \mathrm{t}}{\text { Shareholders' equity by share }_{\mathrm{t}}} \\
\triangle P B V=P B V_{t}-P B V_{t-1}\end{array}$ & - & $\begin{array}{l}\text { Avallone \& Quagli (2015). } \\
\text { Brutting (2011). } \\
\text { Francis et al. (1996). } \\
\text { Stenheim \& Madsen (2016). }\end{array}$ \\
\hline Ret $_{t}$ & $\begin{array}{c}\text { Ret }=\frac{P_{t}-P_{t-1}}{P_{t-1}} \\
P_{t}=\text { Price on } 31 \mathrm{st} \text { December, year } t\end{array}$ & - & $\begin{array}{l}\text { Francis et al. (1996). } \\
\text { Giner \& Pardo (2015). } \\
\text { Godfrey \& Koh (2009). } \\
\text { Rammana \& Watts (2012). } \\
\text { Stenheim \& Madsen (2016). }\end{array}$ \\
\hline $\mathrm{RL} \_n e \mathrm{t}_{\mathrm{t}}$ & Dummy: 1 if RL before Imp_GW is negative, 0 otherwise. & + & $\begin{array}{l}\text { Abuaddous et al. (2014). } \\
\text { Giner \& Pardo (2015). } \\
\text { Godfrey \& Koh (2009). } \\
\text { Walsh et al. (1991). }\end{array}$ \\
\hline $\mathrm{ROE}_{\mathrm{t}}$ & $R O E=\frac{R A I \text { before imp. } G W_{t}}{\text { Shareholders' equity }_{t}}$ & - & $\begin{array}{l}\text { Escribano (2015. } \\
\text { Giner \& Pardo (2015). } \\
\text { Hamberg et al. }(2011) \text {. }\end{array}$ \\
\hline $\operatorname{ROS}_{t}$ & $R O S=\frac{\text { RL before Imp_GW }}{\text { Sales revenues }_{t}}$ & - & $\begin{array}{l}\text { Abuaddous et al. }(2014) \text {. } \\
\text { Jordan \& Clark }(2004,2015) .\end{array}$ \\
\hline $\mathrm{RV}_{-} \mathrm{CEO}_{\mathrm{t}}$ & CEO remuneration in year $t$ & - & Stenheim \& Madsen (2016). \\
\hline
\end{tabular}

\subsection{Models}

According to Baltagi (2005), many economic relationships are dynamic; that is, they contain tuning mechanisms. Therefore, to capture this aspect and at the same time solve the problems of endogeneity which are characteristic of this type of data, the research adopts the system GMM proposed by Blundell and Bond (1998), who showed that the system GMM estimator is more efficient than the simple difference GMM estimator, especially when the autoregressive parameter is moderately high and the number of temporal observations is relatively small. This model is based on a system consisting of two groups of equations: (i) equation with the variables in levels; (ii) equation defined in the first differences of these same variables.

To study the two assumptions formulated, the following general model is defined:

$$
\begin{aligned}
& L n \_i m p \_G W_{i, t}=\beta_{1}^{\ldots} \ln \operatorname{imp}_{-} G W_{i, t-1}+\beta_{2} R L \_n e g{ }_{i, t}+\beta_{3} \operatorname{Debt}_{i, t}+\beta_{4}^{\ldots} \operatorname{Ret}_{i, t}+\beta_{5} G W_{-} a s s e t s, t \\
& \beta_{6} \text { Ln_assets }, t_{+}+\beta_{7} B I G 4_{i, t}+\beta_{8} \Delta P B V_{i t}+\beta_{9} R O E_{i, t}+\beta_{10} R O S_{i, t}+\beta_{11}^{\ldots} R V_{-} C E O R_{i, t}+u_{i, t}
\end{aligned}
$$


In the system GMM method, as instruments we used the outdated Ln_imp_GW variables and the predetermined exogenous variables GW_assets, Ln_assets, RL_neg, Debt, and Ret. The year and BIG4 variables are considered as strictly exogenous.

The general model was estimated for the 2007-2015 period and also for the 2007-2011 and 2012-2015 sub-periods. These sub-periods respond to evidence obtained in the descriptive analysis, namely the magnitude of recognized Imp_GW (see comments to figures 1 to 4 ). The variables of interest RL_neg, Ret, and Debt were controlled by country and by industry, in order to capture the relevance of these structural components.

From the general model, the model for verifying the second hypothesis is deduced. By replacing the Ret and Debt variables with the variables resulting from the interaction of the RL_neg with those variables, it enables it to be ascertained to what extent indebtedness and return are constraints on big bath practices.
All the estimates are carried out in two steps: (i) robust errors and collapse option (GMM), to deal with the proliferation problems of instruments that can lead to biased coefficients (Roodman, 2009a); (ii) the consistency of the estimates is validated using the Hansen and Arellano-Bond tests. Hansen's test concerns restrictions on identification. The null hypothesis states that the instruments are valid, that is, not correlated with the error term, and that those instruments not included are correctly excluded from the estimated model. The Arellano-Bond test tests the hypothesis of the absence of second-order serial correlation in the error term.

\section{Results}

\section{I Descriptive analysis}

Considering some of the relevant indicators for the study, it is worth noting (table 2) that, on average, the Spanish companies, compared to the Portuguese ones, present substantially higher indicators. This demonstrates the size imbalance between the countries.

Table 2.

\section{Characterization of companies - Portugal versus Spain (2007-2015)}

\begin{tabular}{lccc}
\hline Variable (unit: $\left.\mathbf{1 0}^{\mathbf{6}} \mathbf{\epsilon}\right)$ & Average & Portugal & Spain \\
\hline Market value & $3,314.4$ & $1,430.0$ & $4,389.1$ \\
Net earnings (before Imp_GW) & 263.7 & 109.9 & 351.4 \\
Market to Book & 2.2 & 1.9 & 2.4 \\
GW & 831.2 & 303.9 & 1.132 .0 \\
Debt & 0.709 & 0.739 & 0.692 \\
Imp_GW & 11.8 & 1.6 & 17.6 \\
\hline
\end{tabular}

The percentage of companies recognizing Imp_GW is, on average, around $27 \%$, reaching its highest proportion in 2011 (36\%). In the remaining years, the percentage of recognition varies between 20\% (2014) and 30\% (2012). In percentage terms, the Portuguese companies are not substantially different from the Spanish ones as regards the recognition of Imp_GW. Considering the average values (€106), there are already significant differences between the countries, especially in the 2011-2014 period, where the Spanish companies present comparatively high values, which coincide with a higher percentage of companies with RL_neg, before Imp_GW, and a higher average amount of Imp_GW (table 3). 
Table 3.

Recognition Imp_GW, Imp_GW, and RL_neg

\begin{tabular}{|c|c|c|c|c|c|c|c|c|c|c|}
\hline Recognition/Year & 2007 & 2008 & 2009 & 2010 & 2011 & 2012 & 2013 & 2014 & 2015 & Total \\
\hline$\%$ Yes (sample) & $23 \%$ & $28 \%$ & $26 \%$ & $26 \%$ & $36 \%$ & $30 \%$ & $26 \%$ & $20 \%$ & $25 \%$ & $27 \%$ \\
\hline Portugal (\%) & $21 \%$ & $32 \%$ & $25 \%$ & $18 \%$ & $41 \%$ & $25 \%$ & $27 \%$ & $22 \%$ & $25 \%$ & $26 \%$ \\
\hline Spain (\%) & $24 \%$ & $26 \%$ & $28 \%$ & $31 \%$ & $33 \%$ & $31 \%$ & $25 \%$ & $18 \%$ & $27 \%$ & $27 \%$ \\
\hline Average Imp_GW $\left(10^{6} \epsilon\right)$ & 0.7 & 3.7 & 3.2 & 3.8 & 13.2 & 18.1 & 30.4 & 22.2 & 4.3 & 11.1 \\
\hline Portugal $\left(10^{6} €\right)$ & 0.21 & 1.66 & 1.21 & 2.36 & 3.25 & 1.24 & 1.90 & 0.44 & 2.37 & 1.63 \\
\hline Spain $\left(10^{6} €\right)$ & 0.97 & 4.96 & 4.33 & 4.63 & 18.80 & 37.14 & 46.13 & 34.24 & 5.49 & 17.58 \\
\hline Firms RL_neg (\%) & $6 \%$ & $20 \%$ & $25 \%$ & $22 \%$ & $26 \%$ & $36 \%$ & $31 \%$ & $22 \%$ & $26 \%$ & $24 \%$ \\
\hline Portugal (\%) & $12 \%$ & $32 \%$ & $18 \%$ & $12 \%$ & $32 \%$ & $35 \%$ & $21 \%$ & $25 \%$ & $27 \%$ & $24 \%$ \\
\hline Spain (\%) & $3 \%$ & $12 \%$ & $28 \%$ & $28 \%$ & $22 \%$ & $36 \%$ & $37 \%$ & $21 \%$ & $25 \%$ & $24 \%$ \\
\hline
\end{tabular}

The analysis of Imp_GW recognition by company shows that $38 \%$ never recognized goodwill impairments, and $12 \%$ only recognized them once. The practice of recognizing goodwill impairments is evident in most of the analyzed companies $(62 \%)$.

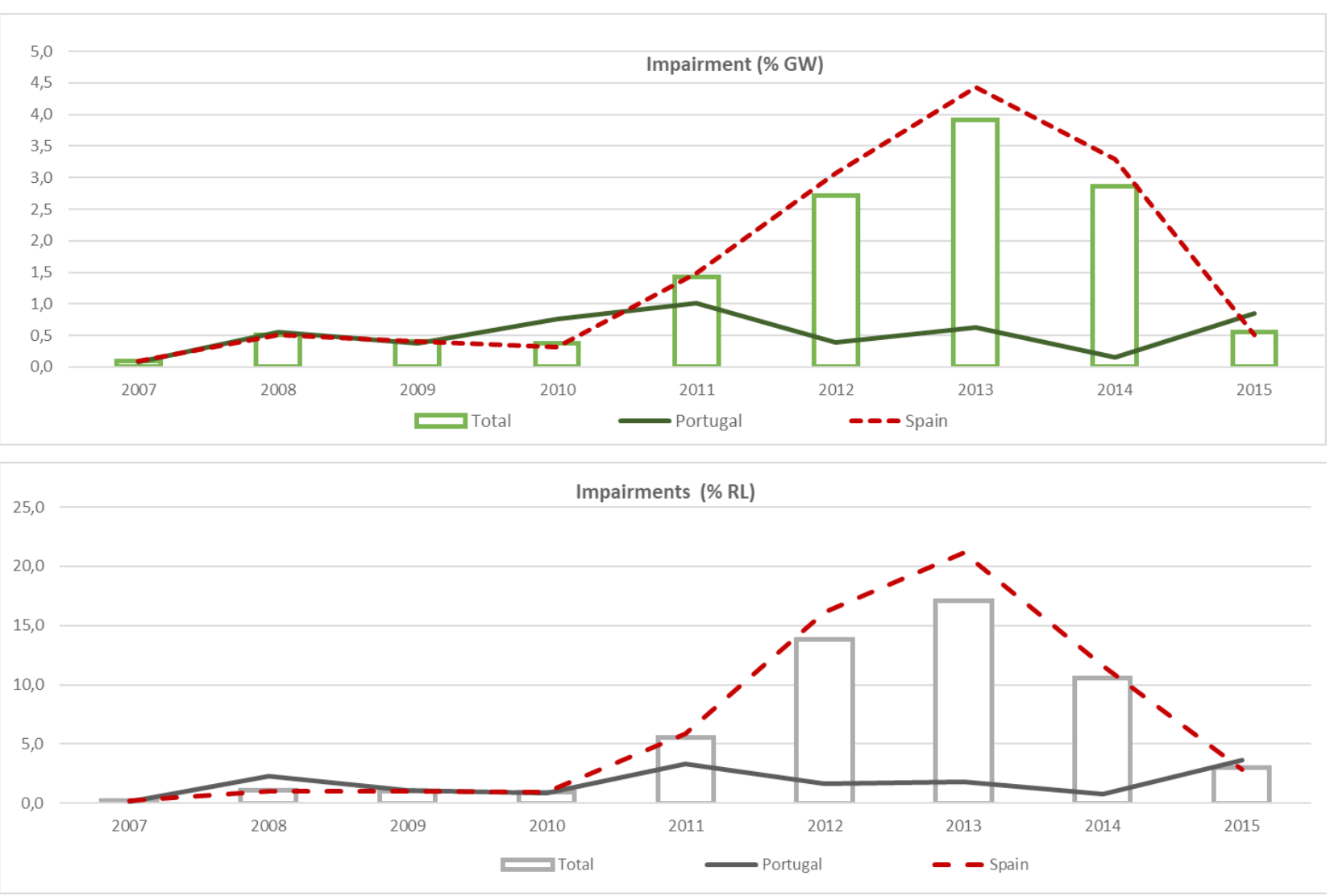

Figure 1. Imp_GW by country (2007-2015) 
The meaning of Imp_GW, a component of RL (Figure 1), is varied. In 2013 Imp_GW accounts for a considerable slice of RL (21.5\%) for the Spanish companies but just 3.3\% for the Portuguese ones. Additionally, Imp_GW as a percentage of GW presents different maximum values between the Spanish (4.4\% in 2013) and Portuguese (1\% in 2011) companies. The distribution of these impairments over the period suggests a diverse pattern of Imp_GW recognition between the companies in each country. While the Portuguese companies show few significant variations, the Spanish ones present a period of strong growth (2011-2014), returning to lower and similar levels to those of the Portuguese companies only in 2015.

The comparison of Imp_GW by country (Figure 1), considering its relative values in relation to Results and GW before Imp_GW, confirms that the Spanish companies present substantially higher values, with prominence in the 2011-2014 period. This cannot be exclusively due to the larger size of the Spanish companies.

Differences between industries are identified. The highest percentage and the highest average amount of Imp_GW are observed in the services industry, while the consumer goods industry has the lowest percentage and lowest average value of Imp_GW. The consumer goods industry shows the lowest average value of GW (183 million euros), which may explain the respective impairments in the 2007-2015 period. The technology and manufacturing industries present substantially higher average GW values (about 2.5 billion euros) but their impairment levels are below the average. This may be associated with the larger amounts and frequencies of Imp_GW in the service industry due to the specificity of investments in this industry, which are possibly more exposed to market contingencies of the business.

An analysis of the behavior of market returns and Imp_GW (Figure 2) suggests the existence of two sub-periods. Initially, there is evidence of an inverse relationship, as Imp_GW increases when market return decreases (20082011), but later increases in Imp_GW are associated with a recovery of market value (20122014). In general, the data suggest that Imp_GW recognition and market value are interconnected variables, with a negative relationship being expected. In the 2011-2012 sub-period there is an association between increased Imp_GW and increased return, suggesting that capital markets can receive the recognition of high losses without reflecting them in the share prices, at least initially. The detailed analysis by country does not identify very different patterns of returns, but instead regarding Imp_GW, which is explained by the magnitude of the Spanish companies (Figure 1).

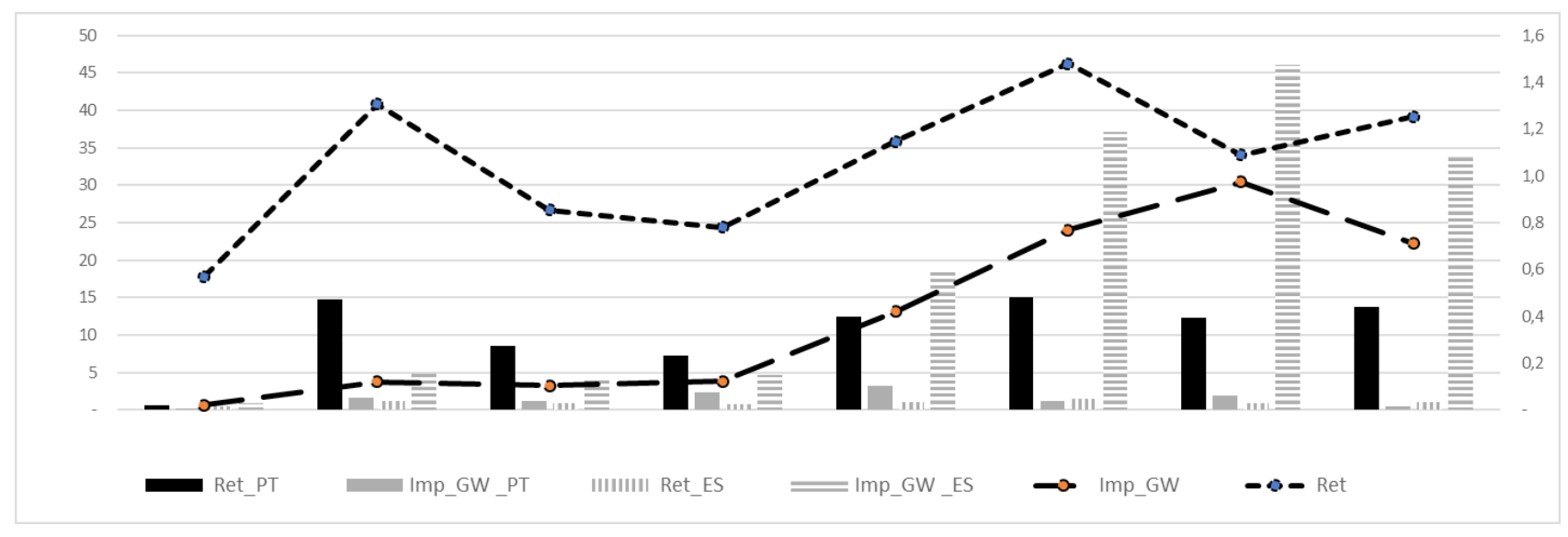

Figure 2. Evolution of Imp_GW (10 6 ) and Ret (2007-2015) 
Turnover (Figure 3) presents no major oscillations in behavior and does not reflect a crisis context in any visible way. However, when associated with significant decreases in results (before Imp_GW), turnover presents a negative variation, except for 2009-2008, 2013-2012, and 2014-2013. The increase in Imp_GW accompanies the years of higher reductions in results and, thus, indicates big bath practices.

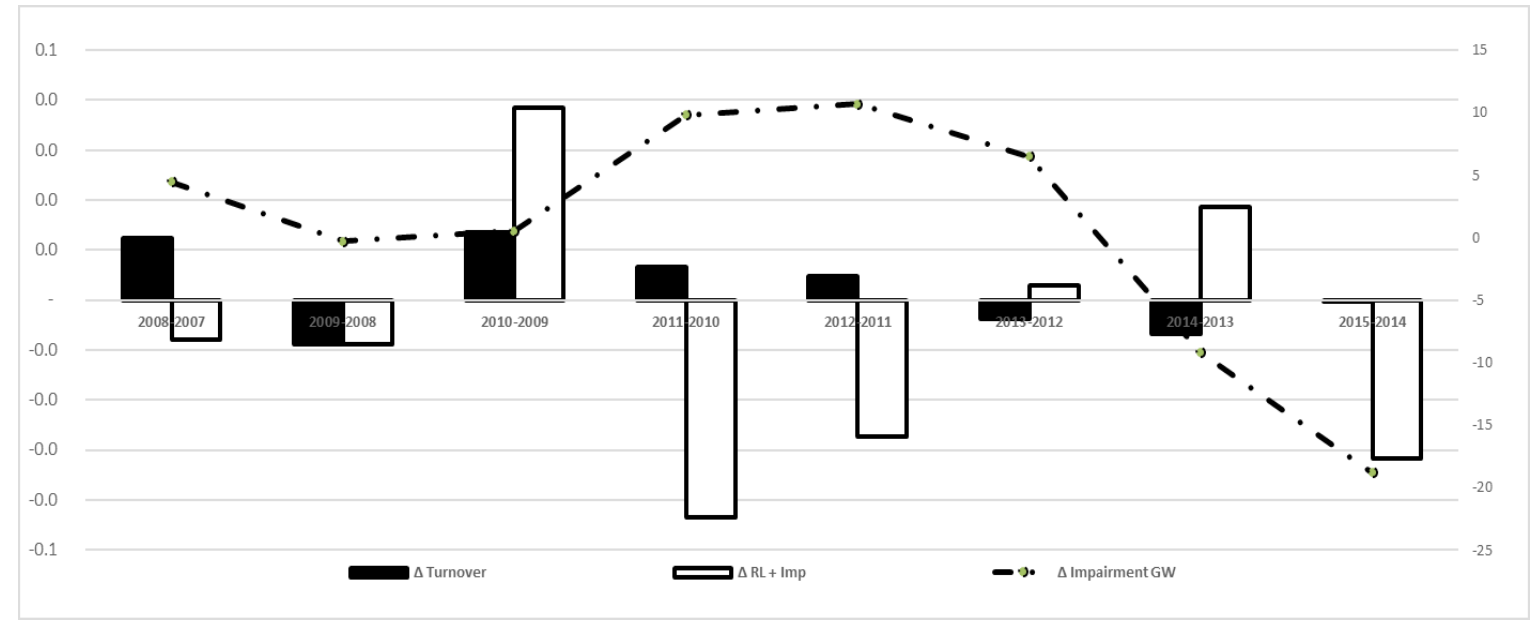

Figure 3. Turnover, RL, and Imp_GW (2007-2015) $\left(10^{6} €\right)$

Throughout the analyzed time horizon, the Portuguese companies are more leveraged than the Spanish ones, only surpassed in 2013 and 2014 by the latter, and coinciding with higher amounts of Imp_GW (Figure 4).

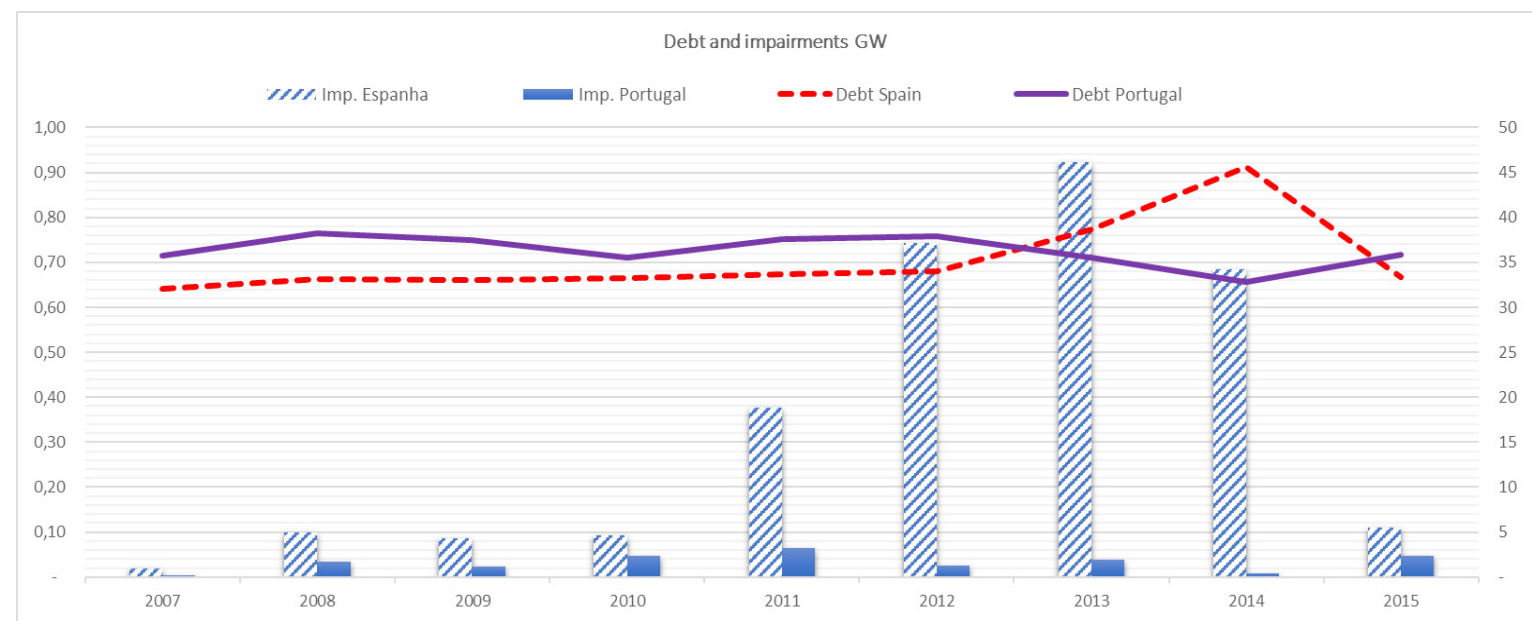

Figure 4. Debt (Percentage) and Imp_GW (10 $€)$ (2007-2015)

The analysis of Imp_GW recognition suggests the existence of two distinct sub-periods. The frontier is in 2011/2012, and is strongly influenced by the behavior of the Spanish companies.

\subsection{Model analysis}

Table 4 presents a summary of the significant results of the estimated regression models. These models test the two assumptions stated in section 2 . 
Table 4.

Results of the estimated models

\begin{tabular}{|c|c|c|c|c|}
\hline \multirow{2}{*}{ Variables } & & \multirow{2}{*}{$\begin{array}{c}\text { Periods } \\
\text { 2007-2015 }\end{array}$} & \multicolumn{2}{|c|}{ Sub periods } \\
\hline & & & $2007-2011$ & 2012-2015 \\
\hline Imp_GW & & $0.2239^{* *}$ & $0.3623^{* *}$ & --- \\
\hline RL_neg ${ }_{t}$ & & $0.4704^{*}$ & --- & $0.1537^{* *}$ \\
\hline \multirow{2}{*}{$\mathrm{RL}_{-}$neg $_{\mathrm{t}}$ (Country) } & Portugal & --- & -- & --. \\
\hline & Spain & $0.7528^{*}$ & --- & $0.8940^{* *}$ \\
\hline \multirow{5}{*}{$R L \_n e g_{t}$ (Industry) } & Manufacturing & $1.2756^{*}$ & $2.6394^{*}$ & -- \\
\hline & Consumer goods & $-2.9203^{*}$ & --- & --- \\
\hline & Services & --- & --- & $1.8777^{*}$ \\
\hline & Energy & --- & --- & --- \\
\hline & Technology & --- & -- & $4.4598^{*}$ \\
\hline Debt $_{t}$ & & $0.4702^{* *}$ & --- & $0.3679^{*}$ \\
\hline $\operatorname{Debt}_{t}$ (RL_neg) & & $0.8196^{* *}$ & --- & $0.9681^{* *}$ \\
\hline \multirow{2}{*}{ Debt $_{t}$ (Country) } & Portugal & --- & -- & -- \\
\hline & Spain & $0.4890^{* *}$ & -- & $0.3389^{*}$ \\
\hline \multirow{5}{*}{ Debt $_{t}$ (Industry) } & Manufacturing & $2.2949^{* *}$ & -- & --- \\
\hline & Consumer goods & --- & -- & --- \\
\hline & Services & --- & --- & --- \\
\hline & Energy & --- & --- & --- \\
\hline & Technology & $7.950^{*}$ & --- & $6.3028^{*}$ \\
\hline Ret $_{t}$ & & $0.1109^{*}$ & $-0.3162^{*}$ & $0.1537^{* *}$ \\
\hline $\operatorname{Ret}_{t}$ (RL_neg) & & --- & $-2.5933^{* *}$ & $0.1265^{* *}$ \\
\hline \multirow{2}{*}{$\operatorname{Ret}_{t}$ (Country) } & Portugal & --- & --- & --- \\
\hline & Spain & $0.1217^{*}$ & --- & $0.1597^{* *}$ \\
\hline \multirow{5}{*}{$\operatorname{Ret}_{t}$ (sector) } & Manufacturing & --- & --- & $0.1140^{* *}$ \\
\hline & Consumer goods & --- & -.- & --- \\
\hline & Services & $0.3201^{* *}$ & --- & $0.986^{* *}$ \\
\hline & Energy & --- & -- & --- \\
\hline & Technology & -- & -- & -- \\
\hline \multicolumn{2}{|l|}{$\mathrm{ROE}_{\mathrm{t}}$} & $-\ldots$ & -- & --- \\
\hline \multicolumn{2}{|l|}{$\triangle \mathrm{PBV}_{\mathrm{T}}$} & --- & --- & --- \\
\hline \multicolumn{2}{|l|}{ GW_assets } & $3.6530^{* *}$ & $9.2167^{* *}$ & -- \\
\hline \multicolumn{2}{|l|}{ Ln_assets } & $0.5922^{* *}$ & $0.5709^{* *}$ & $0.4939^{* *}$ \\
\hline \multicolumn{2}{|l|}{ ROS } & $0.0049^{* *}$ & $0.2625^{* *}$ & $0.0050^{*}$ \\
\hline \multicolumn{2}{|l|}{ BIG4t } & $-1.9218^{* *}$ & --- & --- \\
\hline \multicolumn{2}{|l|}{$\mathrm{RV}_{-} \mathrm{CEO}_{\mathrm{t}}$} & -.- & --- & --- \\
\hline \multicolumn{2}{|l|}{ \# Observations } & 721 & 333 & 265 \\
\hline \multicolumn{2}{|l|}{ \# Groups } & 94 & 93 & 94 \\
\hline \multicolumn{2}{|l|}{ \# Instruments } & 88 & 56 & 84 \\
\hline \multicolumn{2}{|c|}{ Wald chi2 (Prob>chi2) } & $93.05(0.000)$ & $82.28(0.000)$ & $59.52(0.000)$ \\
\hline \multicolumn{2}{|c|}{ Hansen test (Prob>chi2) } & $79.28(0.376)$ & $52.67(0.174)$ & $76.60(0.333)$ \\
\hline \multirow{2}{*}{\multicolumn{2}{|c|}{$\begin{array}{l}\text { Arellano-Bond test (Prob>z) } \\
\text { AR (2) }\end{array}$}} & $-3.42(0.001)$ & $-2.22(0.027)$ & $-1.83(0.068)$ \\
\hline & & $-0.63(0.528)$ & $-1.63(0.104)$ & $-0.55(0.582)$ \\
\hline
\end{tabular}

Note: ${ }^{*} \mathrm{p}<0.05 ;{ }^{* *} \mathrm{p}<0.01$

The results in the various models (table 4) are consistent with the sign and meaning of the generality 
of variables. A positive and significant association is observed in $t$ and $t-1$ regarding Imp_GW recognition. This finding is in line with Escribano (2015) and Francis et al. (1996), who concluded that a history of Imp_GW recognition induces similar behaviors in the future. Another reason that may explain this positive relationship is the delay between the recognition of goodwill losses and the reduction in the value of the underlying asset, allowing managers flexible recognition at the most convenient time. Considering the two subperiods analyzed, it is noted that this relationship is only significant in the 2007-2012 period, suggesting that in the following sub-period other determinant factors overlap.

As far as $\mathrm{H} 1$ is concerned, the results confirm the positive explanatory capacity of RL_neg for the recognition of Imp_GW ( $\mathrm{p}<$ 0.001). According to Li et al. (2011), this suggests the presence of big bath practices with special incidence in the 2012-2015 sub-period, in the Spanish companies, when there was an elevated number of companies with negative earnings (before Imp_GW); this is coincident with higher values of Imp_GW. In four industries, RL_neg is explanatory. RL_neg is positively associated with Imp_GW in the manufacturing, services, and technology industries. However, the opposite is observed in the consumer goods industry, suggesting different practices when faced with bad results.

Regarding the relationship between Imp_GW recognition and market variables, only Ret is a statistically significant variable. A negative relationship between Imp_GW recognition and Ret is observed in the 2007-2011 sub-period, followed by a positive relationship in the next sub-period. This result suggests that companies are sensitive to market signals, whether they penalize impairment losses, or they minimize their impacts. In the first sub-period the expected (negative) ratio is confirmed; that is, market value decreases are associated with impairment increases. However, these impairment increases correspond to relatively low average values, indicating that the market anticipates future losses in a context of economic depression. In the 2012-2015 sub-period, a positive relationship is observed, and only in the Spanish companies. In line with Alciatore et al. (2000), the results suggest that Imp_GW tends to be reported after a fall in the stock price. This suggests that the market already incorporates part of that unfavorable information.

Concerning the analysis restricted to the manufacturing and services industries, a significant positive relationship is observed, these being the two industries where big bath practices were previously identified. These results support the conclusions of Henning et al. (2004), Li and Sloan (2017), Ramanna and Watts (2012), Riedl (2004), and Watts (2003), suggesting that the recognition of Imp_GW is a discretionary act of managers, in terms of the amount and time of the recognition, and thus adjustable to market behavior.

There is a positive, unanticipated association between debt and Imp_GW, which suggests that indebtedness is not a restriction on the recognition of these losses. This relationship is significant only for the Spanish companies (also found by Escribano (2015), but not significant) and in the technology and manufacturing industries and, in particular, in the 20122015 sub-period. These results contradict the assumption of positive accounting theory, but, like in Beatty et al. (2002), it may be concluded that companies are willing to accept higher interest rates to maintain flexibility in their accounting options.

A positive relationship between Imp_GW and company size (Ln_assets, as a proxy) is the association expected and has been found in many studies. The relationship found in this research suggests that, in the context of discretionary use of big bath practices, these are more likely to be used in large companies than in smaller ones, which seems to confirm the results of Elliott and Shaw (1988). Sevin and Schroeder (2005) suggest that using big bath has a greater impact 
on small companies, compared to larger ones, so these extended effects may impose restrictions on the use of such practices. The Size variable can explain the non-evidence of big bath in the Portuguese companies, given that the relative size of these companies is much lower than that of the Spanish ones.

The BIG4 variable is negatively associated with the recognition of Imp_GW. The presence of big bath practices can explain this unanticipated relationship, and suggests opportunistic behaviors in the absence of these auditors. Artur, Tang, and Lin (2015) analyzed the use of discretionary accruals, including Imp_GW, as an earnings management tool and also observed this negative relationship.

The positive relationship between ROS (before Imp_GW) and the dependent variable is also contrary to expected. It is deduced that, in the context of big bath practices, the margin in sales is sacrificed in favor of the objectives that lie in this type of strategy.

Analyzing the market and indebtedness in the recognition of Imp_GW in companies with RL_neg (H2) reveals a pattern equal to that of the total sample, in terms of big bath practices. Indebtedness is not confirmed as a factor in adopting these practices, while the market is confirmed as such (negative relationship) in the 2007-2011 sub-period and is not confirmed as such in the 2012-2015 sub-period (positive relationship), as explained above.

\section{Conclusions}

This paper analyzed the recognition of goodwill impairment (Imp_GW) as a big bath strategy, as well as any restrictions on this policy. The research is based on a sample of companies with shares listed on the Lisbon and Madrid stock markets in the 2007-2015 period, which includes years of economic recession (2009-2013) in both countries, Portugal and Spain.

It is noted that $38 \%$ of the companies never recognized $I m p_{-} G W$ throughout the years from 2007 to 2015 , but the positive and meaningful association between $I M P_{-} G W_{t}$ and Imp_GWt-1 reflects the predisposition towards such recognition when there is already such an experience. This conclusion is in line with previous findings by Escribano (2015) and Francis et al. (1996).

Imp_GW seems to play a relevant role in big bath practices in companies with negative earnings. This result corroborates the existence of high discretion in the use of non-recurring accruals, and is consistent with the conclusions of Li et al. (2011). The negative relationship between the BIG4 variable and goodwill impairment suggests practices that go against credible accounting, so large audit companies do not seem to be able to discourage these practices.

In the analysis for the 2007-2011 and 2012-2015 sub-periods, big bath practices are only significant in the latter, and only for Spanish companies. These coincide with the highest percentage of companies with negative earnings, corrected by Imp_GW, and with the highest amount of these losses. The fact that only the Spanish companies have significant relationships regarding big bath practices or the impact of market and debt variables may be explained by the fact that they are, on average, larger than the Portuguese ones (the former are about 2.5 times larger in turnover and approximately three times bigger in stock market capitalization than the latter) and have a higher average amount of Imp_GW (about 11 times) concentrated in this specific period. On the other hand, the RL_neg indicates that although size attracts greater public exposure, these companies tend to have a greater capacity to minimize the impact of the recognition of these losses. This confirms one of the assumptions of positive accounting theory that associates company size with policies that manipulate accounting and tend to sacrifice present results for the sake of future profits.

The various industries do not present homogeneous behavior regarding the relationship between RL_neg and Imp_GW. The consumer goods industry stands out with a negative 
relationship between the two variables, suggesting the non-penalizing of results by Imp_GW. This is interpreted as being due to the nature of the diverse activities, particularly the exposure of investments to specific and systemic risks, which are aggravated in times of crisis.

Additionally, this research analyzed to what extent debt and the capital market are constraints to big bath practices in companies with RL_neg. The positive relationship found between indebtedness and Imp_GW suggests that any penalties for creditors do not affect the recognition of goodwill impairments, nor do they limit big bath practices. Although several of these companies are financed with publicly traded debt instruments, funding by credit institutions plays an important role, and these large companies have significant negotiating power, so they are not severely affected by occasional bad results. The relationship between the level of indebtedness and Imp_GW is only positive and significant in the Spanish companies, suggesting that the differences in size influence negotiating power with relation to creditors. These results contradict the assumption of positive accounting theory, but as found by Beatty et al. (2002), it can be concluded that companies are willing to accept higher interest rates to maintain flexibility in their accounting options.

The study included years of crisis (20092013), but also years of economic recovery (20142015) and capital market recovery (2012-2013), in its examination of the relationship between the Ret variable and Imp_GW in companies with negative earnings. Different situations were found in the two sub-periods, 2007-2011 and 20122015. While in the former there is a negative (expected) relationship between market signals and the recognition of Imp_GW; in the later sub-period there is a positive relationship, where a significant reduction in results is combined with recovery in market return. The big bath practices occurred in an environment where, on the one hand, the market does not penalize Imp_GW and, on the other, companies manage Imp_GW in line with the expected reactions of the market. In agreement with the conclusions of Alciatore et al. (2000), this research suggests that Imp_GW losses tend to be reported after a fall in the stock price because the capital market has already incorporated them, at least in part.

There is evidence of opportunistic earnings management, in addition to the accounting choice that international financial reporting standards permit (Libby, Rennekamp \& Seybert, 2015; McEnroe \& Sullivan, 2014).

The results obtained refer to a temporal horizon that includes years of economic depression, which may have influenced the behavior of the companies in terms of their recognition of Imp_GW, and no other factors were identified as facilitators or inhibitors of earnings management, notably variables related to corporate governance and more detailed information on the cash generating units, which should be considered in future studies.

The results indicate that the internal and external accounting control mechanisms are not effective in preventing and controlling the opportunistic use of accounting policies as an instrument for manipulating the accounting truth when faced with certain objectives. This study contributes to the literature because it analyzes factors (indebtedness and market) as potential constraints on big bath practices and suggests that the accounting and financial reporting standardsetters should consider alternatives that minimize the discretionary power of managers.

\section{References}

Abuaddous, M., Hanefah, M., \& Laili, N. (2014). Accounting standards, goodwill impairment, and earnings management in Malaysia. International Journal of Economics and Finance, 6(12), 201-211. doi:10.5539/ijef.v6n12p201.

AbuGhazaleh, N., Al-Hares, O., \& Roberts, C. (2011). Accounting discretion in goodwill impairments: UK evidence. Journal of International Financial Management and Accounting, 22(3), 
165-204. doi:10.1111/j.1467-646X.2011.01049. $\mathrm{x}$.

Alciatore, M., Easton, P., \& Spear, N. (2000). Accounting for the impairment of long-lived assets: Evidence from the petroleum industry. Journal of Accounting and Economics, 29(2), 151172.

Alves, S. (2013). The association between goodwill impairment and discretionary accruals: Portuguese evidence. Journal of Accounting Business \& Management, 20(2), 84-98.

Artur, N., Tang, Q., \& Lin, Z. (2015). Corporate accruals quality during the 2008-2010 Global Financial Crisis. Journal of International Accounting Auditing and Taxation, 25, 1-15. doi:10.1016/j. intaccaudtax.2015.10.004.

Avallone, F., \& Quagli, A. (2015). Insight into the variables used to manage the goodwill impairment test under IAS 36. Advances in Accounting, 31(1), 107-114. doi:10.1016/j.adiac.2015.03.011.

Baltagi, B. (2005) Econometric analysis of panel data (3rd ed.). Chichester: Wiley.

Bamber, L., \& Cheon, Y. (1998). Discretionary management earnings forecast disclosures: Antecedents and outcomes associated with forecast venue and forecast specificity choices. Journal of Accounting Research, 36(2), 167-190. doi: $10.2307 / 2491473$.

Banco Mundial (2018). World Development Indicators [on line]. Available at https:// datacatalog.worldbank.org/dataset/worlddevelopment-indicators.

Beatty, A., \& Weber, J. (2006). Accounting discretion in fair value estimates: An examination of SFAS 142 goodwill impairments. Journal of Accounting Research, 44(2), 257-288.
doi:10.1111/j.1475-679X.2006.00200.x.

Beatty, A., Ramesh, K. \& Weber, J. (2002). The importance of accounting changes in debt contracts: The cost of flexibility in covenant calculations. Journal of Accounting and Economics, 33(2), 205-227. doi:10.1016/S01654101(02)00046-0.

Beatty, A., Weber, J., \& Yu, J. (2008). Conservatism and debt. Journal of Accounting and Economics, 45(2-3), 154- 174. doi:10.1016/j. jacceco.2008.04.005.

Blundell, R., \& Bond, S. (1998). Initial conditions and moment restrictions in dynamic panel data models, Journal of Econometrics, 87(1), 115-143.

Brütting, M. (2011). Goodwill Impairment Causes and Impact (Doctoral thesis). City University, London, UK.

Caplan, J. \& Harris, R. (2002). Coming into focus: New merger-accounting rules may sharpen investors' views of intangibles, but CFOs should also consider the impact of write-offs. CFO, 18, 53-54.

Carvalho, C. (2015). O Goodwill e o seu tratamento contabilístico após adoção das IFRS: Uma análise nas empresas da Euronext Lisbon (Doctoral Thesis). Universidade de Aveiro, Aveiro, PO.

Castro, E. (2012). A Manipulação de resultados em Portugal através do goodwill (Master's Thesis). Instituto Politécnico do Porto, Porto, Portugal.

Chalmers, K. Godfrey, J., \& Webster, J. (2011). Does a goodwill impairment regime better reflect the underlying economic attributes of goodwill? Accounting e Finance, 51(3), 634-660. doi:10.1111/j.1467-629x.2010.00364.x.

Chen, C., Kohlbeck, M., \& Warfield, T. (2008). Timeliness of impairment recognition: Evidence from the initial adoption of SFAS 142. Advances in Accounting, 24(1), 72-81. doi:10.1016/j. 
adiac.2008.05.015.

Elliott, J. \& Hanna, J. (1996). Repeated Accounting Write-Offs and the Information Content of Earnings. Journal of Accounting Research, 34, 135-155. doi: 10.2307/2491430.

Elliott, J. \& Shaw, W. (1988). Write offs as accounting procedures to manage perceptions. Journal of Accounting Research, 26, 91-119. doi:10.2307/2491182.

Escribaño, J. (2015). Análisis de la discrecionalidad en el reconocimiento del deterioro del fondo de comercio: Un estudio empirico (Doctoral Thesis). Universidad Complutense, Madrid, Spain.

Eurostat (2018). Contas nacionais e PIB [online]. Retrieved from https://ec.europa.eu/eurostat/ statistics-explained/index.php?title=National_ accounts_and_GDP/pt\#Contas_Nacionais_e_ PIB

Fernandes, J., Gonçalves, C., Guerreiro, C., \& Pereira, L. (2016). Perdas por imparidade: fatores explicativos, Revista Brasileira de Gestão e de Negócios, 18(60), 305-318. doi: 10.7819/rbgn. v18i60.2300

Francis, J., Hanna, D., \& Vincent, L. (1996). Causes and effects of discretionary asset write off. Journal of Accounting Research, 34(3), 117-134. doi:10.2307/2491429

Giner, B., \& Pardo, F. (2015). How ethical are managers' goodwill impairment decisions in Spanish-listed firms? Journal of Business Ethics, 132(1), 21-40. doi:10.1007/s10551-014-2303-8

Godfrey, J., \& Koh P. (2009). Goodwill impairment as a reflection of investment opportunities. Accounting and Finance, 49(1), 117-140. doi:10.1111/j.1467-629X.2008.00272.x

Hamberg, M., Paananen, M., \& Novak. J. (2011). The adoption of IFRS 3: The effects of managerial discretion and stock market reactions.
European Accounting Review, 20(2), 263-288. doi:10.1080/09638181003687877

Henning, L., Shaw, H., \& Stock, T. (2004). The amount and timing of goodwill write-offs and revaluations: Evidence from U.S. \& U.K. firms. Review of Quantitative Finance and Accounting, 23(2), 99-121. doi:10.1023/B: REQU.0000039507. 82692.d3

Holthausen, W., \& Watts, L. (2001). The relevance of the value-relevance literature for financial accounting standard setting. Journal of Accounting and Economics, 31(1-3), 3-75. doi:10.1016/S0165-4101(01)00029-5

Jahmani, Y., Dowling, A. \& Torres, D. (2010). Goodwill impairment: A new window for earnings management? Journal of Business \& Economics Research, 8(2), 19-23. doi:10.19030/ jber.v8i2.669

Jarva, H. (2009). Do firms manage fair value estimates? An examination of SFAS 142 goodwill impairments. Journal of Business Finance and Accounting, 36(9-10), 1059-1086. doi:10.1111/j.1468-5957.2009. 02169.x.

Jordan, E., \& Clark, J. (2004). Big bath earning management: The case of GW impairment under SFAS no. 142. Journal of Applied Business Research, 20(2), 63-69.

Jordan, E., \& Clark, J. (2015). Do New CEOs practice big bath earnings management via goodwill impairments? Journal of Accounting and Finance, 15(7), 11-21.

Lapointe-Antunes, P., Cormier, D., \& Magnan, M. (2008). Equity Recognition of mandatory accounting changes: The case of transitional goodwill impairment losses. Canadian Journal of Administrative Sciences, 25(1), 37-54. doi: 10.1002/cjas.41.

La Porta, R., Lopez-de-Silanes, F., Shleifer, A., \& Vishny, R. (1997). Legal determinants of external 
finance. The Journal of Finance, 52(3), 1131-1150. doi: 10.1111/j.1540-6261.1997.tb02727.x

Lee, C. (2011). The effect of SFAS 142 on the ability of goodwill to predict future cash flows. Journal of Accounting and Public Policy, 30(3), 236-255. doi:10.1016/j.jaccpubpol.2010.11.001

Li, K., \& Sloan, G. (2017). Has goodwill accounting gone bad? Review of Accounting Studies, 22(2), 964-1003. doi:10.2139/ssrn.1466271

Li, Z., Shroff, P., Venkataraman, R., \& Zhang. I. (2011). Causes and consequences of goodwill impairment losses. Review of Accounting Studies, 16(4), 745-778. doi:10.1007/s11142-011-9167-2.

Libby, R., Rennekamp, K., \& Seybert, N. (2015). Regulation and the interdependent roles of managers, auditors, and directors in earnings management and accounting choice, Accounting, Organizations and Society, 47, 25-42. doi:10.1016/j.aos.2015.09.003

McEnroe, J., \& Sullivan, M. (2014). An examination of the perceptions of auditors and chief financial officers of various regulations introduced by the Dodd-Frank financial reform bill. Advances in Public Interest Accounting, 16, 187-220. doi: 10.1108/S1041-7060(2013)0000016010

Nobes, C., \& Parker, R. (2004). Comparative International Accounting. London: Prentice Hall.

Olante, M. (2013). Overpaid acquisitions and goodwill impairment losses — Evidence from the US. Advances in Accounting, 29(2), 243-254. doi:10.1016/j.adiac.2013.09.010.

Ramanna, K., \& Watts, R. (2012). Evidence on the use of unverifiable estimates in required goodwill impairment. Review Accounting Studies, 17(4), 749-780. doi:10.1007/s11142-012-9188-5.

Riedl, E. (2004). An Examination of Long-Lived Asset Impairments. The Accounting Review, 79(3), 823-852. doi: 10.2308/accr.2004.79.3.823
Roodman, D. (2009a). How to do xtabond2: An introduction to difference and system GMM in Stata. Stata Journal, 9(1), 86-130.

Roodman, D. (2009b). A note on the theme of too many instruments. Oxford Bulletin of Economics and Statistics, 71(1), 135-158.

Sevin, S., \& Schroeder, R. (2005). Earnings management: Evidence from SFAS no. 142 reporting. Managerial Auditing Journal, 20(1), 47-54. doi:10.1108/02686900510570696

Stenheim, T., \& Madsen, D. (2016). Goodwill impairment losses, economic impairment, earnings management and corporate governance. Journal of Accounting and Finance, 16(2), 11- 29.

Transparency International (2016). Corruption Perceptions Index 2015 [online]. Retrieved from http://issuu.com/transparencyinternational/ docs/2015_corruptionperceptionsindex_ rep?e $=2496456 / 33011041$.

Van de Poel, K., Maijoor, S., \& Vanstraelen, A. (2009). IFRS goodwill impairment test and earnings management: The influence of audit quality and the institutional environment. Retrieved from http://www.fdewb.unimaas. nl/ ISAR2009/02_17_Van_de_Poel_Maijoor_ Vanstraelen.pdf.

Vogt, M., Pletsch, C., Morás, V., \& Klann, R. (2016). Determinantes do reconhecimento das perdas por impairment do goodwill. Revista de Contabilidade e Finanças, 27(72), 349-362. doi:10.1590/1808-057x201602010.

Xu, Y., Carson, E., Fargher, N., \& Jiang, L. (2013). Responses by Australian auditors to the global financial crisis. Accounting e Finance, 53(1), 301-338. doi: 10.111/j.1467-629x.2011.00459.x

Walsh, P., Craig, R., \& Clarke, F. (1991). Big bath accounting using extraordinary items adjustments: Australian empirical evidence. Journal of Business Finance \& Accounting, 18(2), 
173-189. doi:10.1111/j.1468-5957.1991. tb00587.x

Watts, R. (2003). Conservatism in accounting Part I: Explanations and implications. Accounting Horizons, 17(3), 207-221. doi:10.2308/ acch.2003.17.3.207

Watts, R., \& Zimmerman, J. (1978). Towards a positive theory of the determination of accounting standards. The Accounting Review, 53(1-January), 112-134.
Watts, R., \& Zimmerman, J. (1990). Positive accounting theory a ten-year perspective. The Accounting Review, 65(1), 131-156.

World Federation of Exchanges (2016). WFE Annual Statistics Guide 2016 [on line]. Retrieved from https://www.world-exchanges.org/home/ index.php/statistics/annual-statistics\#ASG.

Zhang, J. (2008). The contracting benefits of accounting conservatism to lenders and borrowers. Journal of Accounting and Economics, 45(1), 2754. doi:10.1016/j.jacceco.2007.06.002.

About the Authors:

Cristina Gonçalves, Master in Economic and Business Science, Universidade do Algarve. E-mail: cjesus@ualg.pt; ORCID

(iD) 0000-0003-2671-9024

2. Leonor Ferreira, Ph.D in Management, Universidade Lusíada de Lisboa. E-mail: leonor.ferreira@novasbe.pt ORCIID

(iD) 0000-0002-6544-7511

3. Efigénio Rebelo, Ph.D in Economic Sciences (Econometrics), Universidade do Algarve. E-mail: elrebelo@ualg.pt; ORCID

(iD) 0000-0003-1965-965

4. Joaquim Santana Fernandes, Ph in Administration, Universidade de Algarve. E-mail: jsfer@ualg.pt; ORCIID

(iD) 0000-0003-2768-1611

\section{Contribution of each author}

\begin{tabular}{|c|c|c|c|c|}
\hline Contribution & $\begin{array}{c}\text { Cristina } \\
\text { Gonçalves }\end{array}$ & $\begin{array}{l}\text { Leonor } \\
\text { Ferreira }\end{array}$ & $\begin{array}{c}\text { Efigénio } \\
\text { Rebelo }\end{array}$ & $\begin{array}{l}\text { Joaquim } \\
\text { Fernandes }\end{array}$ \\
\hline 1. Definition of research problem & $\sqrt{ }$ & $\sqrt{ }$ & & \\
\hline 2. Development of hypotheses or research questions (empirical studies) & $\sqrt{ }$ & $\sqrt{ }$ & & \\
\hline 3. Development of theoretical propositions (theoretical work) & $\sqrt{ }$ & $\sqrt{ }$ & & \\
\hline 4. Theoretical foundation/ Literature review & $\sqrt{ }$ & $\sqrt{ }$ & & \\
\hline 5. Definition of methodological procedures & $\sqrt{ }$ & & $\sqrt{ }$ & $\sqrt{ }$ \\
\hline 6. Data collection & $\sqrt{ }$ & & & $\sqrt{ }$ \\
\hline 7. Statistical analysis & $\sqrt{ }$ & & $\sqrt{ }$ & $\sqrt{ }$ \\
\hline 8. Analysis and interpretation of data & $\sqrt{ }$ & & & $\sqrt{ }$ \\
\hline 9. Critical revision of the manuscript & $\sqrt{ }$ & $\sqrt{ }$ & $\sqrt{ }$ & \\
\hline 10. Manuscript writing & $\sqrt{ }$ & $\sqrt{ }$ & & \\
\hline 11. Other (please specify which) & & & & \\
\hline
\end{tabular}

